\title{
Physico-chemical characterization and antibacterial activity of inclusion complexes of Hyptis martiusii Benth essential oil in $\beta$-cyclodextrin
}

\author{
Tatianny A. Andrade ${ }^{\mathrm{a}}$, Thiago S. Freitas ${ }^{\mathrm{b}}$, Francielly O. Araújo ${ }^{\mathrm{a}}$, Paula P. Menezes ${ }^{\mathrm{a}}$, \\ Grace Anne A. Dória ${ }^{a}$, Alessandra S. Rabelo ${ }^{a}$, Lucindo J. Quintans-Júnior ${ }^{c}$, \\ Márcio R.V. Santos ${ }^{c}$, Daniel P. Bezerra ${ }^{\mathrm{d}}$, Mairim R. Serafini ${ }^{\mathrm{a}}$, Irwin Rose A. Menezes ${ }^{\mathrm{e}}$, \\ Paula Santos Nunes ${ }^{c}$, Adriano A.S. Araújo ${ }^{a}$, Maria S. Costab ${ }^{b}$ Fábia F. Campina ${ }^{\text {, }}$ \\ Antonia T.L. Santos ${ }^{\mathrm{b}}$, Ana R.P. Silva ${ }^{\mathrm{b}}$, Henrique D.M. Coutinho ${ }^{\mathrm{b}, *}$ \\ a Pharmacy Department, Federal University of Sergipe, Sergipe, Brazil \\ b Department of Biological Chemistry, Regional University of Cariri, Crato, Ceará, Brazil \\ ${ }^{\mathrm{c}}$ Physiology Department, Federal University of Sergipe, Sergipe, Brazil \\ d Gonçalo Muniz Research Center, Oswaldo Cruz Foundation, Bahia, Brazil \\ e Department of Mineralogy and Geotectonics, Institute of Geosciences, University of SãoPaulo-SP, Brazil
}

\section{A R T I C L E IN F O}

\section{Article history:}

Received 4 October 2016

Received in revised form 19 January 2017

Accepted 28 January 2017

\section{Keywords:}

Essential oil

Hyptis martiusii

$\beta-C D$

Inclusion complex

Modulatory-antibiotic activity

Antibacterial activity
A B S T R A C T

Cyclodextrins (CDs) have been used as important pharmaceutical excipients for improve the physicochemical properties of the drugs of low solubility as the essential oil of Hyptis martiusii. This oil is important therapeutically, but the low solubility and bioavailability compromises your use. Therein, the aim of this study was to obtain and to characterize physico-chemically the samples obtained by physical mixture (PM), paste complexation (PC) and slurry complexation (SC) of the essential oil Hyptis martiusii (EOHM) in $\beta-\mathrm{CD}$, and to compare the antibacterial and modulatory-antibiotic activity of products obtained and oil free. The physicochemical characterization was performed by differential scanning calorimetry (DSC), thermogravimetry/derivative thermogravimetry (TG/DTG), scanning electron microscopy (SEM), X-ray diffraction (XRD) and Karl Fischer titration. Additionally, the antibacterial tests were performed by microdilution technique. Thus, it was observed that the PM method showed low complexing capacity, unlike PC and SC in which it was observed the formation of inclusion complexes. In addition, the second stage of the TG/DTG curves showed that SC was the best method inclusion with mass loss of $6.9 \%$ over the PC that was 6.0\%. The XRD results corroborate with the results above suggesting the formation of new solid phase and the SEM photomicrographs showed the porous surface of the samples PC and SC. The essential oil alone demonstrated an antibacterial and modulatory effect against the S. aureus and the Gram negative strain, respectively. However, the $\beta-C D$ and the inclusion complex did not demonstrate any biological activity in the performed antibacterial assays. (c) 2017 Elsevier Masson SAS. All rights reserved.

\section{Introduction}

The Hyptis genus belongs to the Lamiaceae family and is used in the folk medicine as an alternative therapy in the diseases treatment. Some of these species, such as Hyptis fruticosa, Hyptis

\footnotetext{
* Corresponding author at: Laboratório de Microbiologia e Biologia Molecular, Universidade Regional do Cariri, Crato, Ceará, Brazil. Tel.: +55 883102 1212/88 3102 1204.

E-mail address: hdmcoutinho@gmail.com (H.D.M. Coutinho).
}

suaveolens, Hyptis pectinata, are characterized by the presence of essential oils with pharmacological properties, such as antibacterial [1], antiseptic [2], antiulcer [3], antinociceptive [4], antiinflammatory[5,6], among others.

The species Hyptis martiusii Benth, known as "cidreira do campo" or "cidreira brava" is a small shrub, commonly found in the northern, southeastern and northeastern Brazil [7]. In folk medicine, infusion or decoction of Hyptis martuisii leaves are used to combat diseases of the gastrointestinal tract while the decoction of the root misused to combat inflammation of ovaries [8]. In studies with Hyptis martiusii species were identified a number of 
activities, including cytotoxic and antiproliferative effects in certain tumor cell lines [9,10], insecticidal activity [11], antimicrobial [12] and antiulcerogenic [13], highlighting the pharmacological potential of this specie.

In this context, essential oils can be defined as complex mixtures of volatile organic compounds produced as secondary metabolites of plants. Many of them have demonstrated antibacterial activity, alone or associated with antibiotics, by different mechanisms, difficulting the bacterial adaptation and avoiding the resistance surveillance [14,15]. They are made up of hydrocarbons and oxygenate compounds [16]. In the literature, the Hyptis martiusii essential oil (EOHM) is described as comprised of monoand sesquiterpenes, and has as major component 1,8-cineole (24.3\%), $\delta$-3-carene (22.5\%), bicyclogermacrene(6.3\%) and $\beta$-caryophyllene (6.2\%) [17].

Thus, the incorporation of volatile oils in cyclodextrins has been applied to protect the compounds against temperature, oxidation, evaporation and humidity [18]. The use of complexing molecules can be used to combat the bacterial resistance also, reducing the concentration of the drugs and the necessary doses used in the treatment [19]. Besides, the use of molecules with characteristics of to form inclusion complex as CDs associated with antimicrobial drugs can be enhanced the water solubility and extend the half-life in the system of these drugs [20].

Cyclodextrins (CDs) are oligosaccharides composed of 6, 7, 8 or 9 glucopyranose units ( $\alpha-, \beta-, \gamma-$ or $\delta-C D$, respectively), with a relatively hydrophilic surface and a hydrophobic central cavity $[21,22]$. The cyclodextrin inclusion complex formation has been successfully applied to enhance the chemical stability, solubility and bioavailability of poorly soluble compounds [22-24]. The minimum requirement for the complex to be formed is the compatibility of sizes and geometries between the CD cavity and the guest. It has also to consider the hydrophobic character of the guest, thus the polarity is a conditioning factor in the formation of the inclusion complex [25].

The objective of this study was to elucidate the complexation of EOHM in $\beta-C D$, by different methods, and to evaluate the antibacterial and modulatory-antibiotic effect of the best formulation obtained in comparison of oil free. The samples were characterized by differential scanning calorimetry (DSC), thermogravimetry/derivative thermogravimetry (TG/DTG), scanning electron microscopy (SEM), X-ray diffraction (XRD) and moisture content determined by Karl Fischer titration method.

\section{Material and methods}

\subsection{Material}

The $\beta$-CD (Lot:\#041M1759V; purity $\geq 97 \%$ ) was purchased from Sigma-Aldrich (USA) and the EOHM was extracted by hydrodistillation of Hyptis martiusii leaves collected in the savannah area of the Chapada do Araripe (Barreiro Grande Farm, Crato-Ce, $7^{\circ} 21^{\prime} 50^{\prime \prime} \mathrm{S} ; 39^{\circ} 28^{\prime} 39^{\prime \prime} \mathrm{W}$, elevation: $930 \mathrm{~m}$ ) in May/2012. A voucher of the plant specimen was deposited in the Carirense Dárdano de Andrade Lima Herbarium - HCDAL of the Regional University of Cariri - URCA, under registration number 8394. The plant was identified and classified by Prof. Maria Arlene Pessoa da Silva.

\subsection{Sample preparation}

\subsubsection{Extraction of the essential oil}

Fresh leaves samples $(3.950 \mathrm{~g})$ from their natural habitat were collected, washed in running water, pulverized submitted to hydrodistillation $(4 \mathrm{~h})$ using a modified clevenger-type apparatus. The biphasic mixture is formed by the essential oil in the superior phase and the aqueous phase, which is separated through decantation, dried over anhydrous $\mathrm{Na}_{2} \mathrm{SO}_{4}$, kept in amber bottle flask and maintained in temperature lower than $4{ }^{\circ} \mathrm{C}$. The yield $(0.34 \%, w / w)$ of essential oil was calculated based on oil volume produced and fresh leaves mass in $\mathrm{kg}$. The oil of yellowish coloration and characteristic odor was evaluated.

\section{Complexation with $\beta$-cyclodextrins ( $\beta$-CD)}

The samples were prepared by techniques of physical mixture (PM), paste complexation (PC) and slurry complexation (SC). Thus, in the PM method, EOHM (154 mg, based on the molecular weight of the major component, 1,8-cineole) and the $\beta-C D(1135 \mathrm{mg})$ were mechanically mixed by $10 \mathrm{~min}$ in the molar ratio of $1: 1$ in ambient temperature. For to obtain the PC, the EOHM (154 mg) and $\beta-C D$ $(1135 \mathrm{mg})$ were mixed with the aid of a mortar and pestle $(1: 1$ molar ratio) and adding then $2.0 \mathrm{~mL}$ of distilled water with constant manual stirring until forming a paste. Then, the material was kept in a desiccator until dry. Finally, the SC was performed by mechanical mixture of EOHM $(154 \mathrm{mg})$ and $\beta-C D(1135 \mathrm{mg})$ in a molar ratio of $1: 1$ and then $20 \mathrm{~mL}$ of water was added, and remained under constant magnetic stirring at $150 \mathrm{rpm}$ for $36 \mathrm{~h}$. Subsequently, the material was stored in a desiccator until dry.

\subsection{Differential scanning calorimetry (DSC)}

The EOHM, $\beta-C D$, PM and of inclusion complexes samples were subjected to DSC test. The DSC curves were obtained using a DSC50 cell, from Shimadzu, using a heating rate of $10^{\circ} \mathrm{C} / \mathrm{min}$. The DSC curves were obtained between 25 and $500^{\circ} \mathrm{C}$ under a dynamic atmosphere of $\mathrm{N}_{2}(50 \mathrm{~mL} / \mathrm{min})$, employing aluminum capsules ( $\mathrm{Al}$ ) containing $\sim 2 \mathrm{mg}$ of the samples. The DSC cell was calibrated with indium (melting point $156.6^{\circ} \mathrm{C} ; \Delta H_{\text {fus }}=28.54 \mathrm{~J} / \mathrm{g}$ ) and zinc (melting point $\left.419.6^{\circ} \mathrm{C}\right)$.

\subsection{Thermogravimetry/derivative thermogravimetry (TG/DTG)}

The EOHM, $\beta-C D, P M$ and inclusion complexes samples were tested in a TG/DTG apparatus. The TG/DTG curves were obtained using TGA-51 thermobalance, from Shimadzu, using a heating rate of $10^{\circ} \mathrm{C} / \mathrm{min}$. The TG/DTG were conducted at $25-900{ }^{\circ} \mathrm{C}$ range under a dynamic atmosphere of $\mathrm{N}_{2}(50 \mathrm{~mL} / \mathrm{min})$ using platinum (Pt) capsules containing $\sim 3 \mathrm{mg}$ of the samples. The thermogravimetric system was verified using $\mathrm{CaC}_{2} \mathrm{O}_{4} \cdot \mathrm{H}_{2} \mathrm{O}$, reference substance, in accordance with the ASTM standard.

\subsection{Determination of moisture content by the Karl Fischer method}

The moisture content of the PM and the inclusion complexes were determined by Karl Fischer method, model Titrino Plus KF870 (Metrohm), and methanol (Fluka) was used as a titration solution. Analyses were performed in triplicate.

\subsection{Scanning electron microscopy (SEM)}

The $\beta-C D, P M, P C$ and SC samples were mounted on aluminum stubs subsequently plated with gold beams and viewed in an electron microscope (JEOL JSM-6390-LV model) in acceleration voltage of $12 \mathrm{kV}$.

\subsection{X-ray diffraction (XRD)}

The X-ray diffraction of the products were obtained in a Siemens D 5000 equipment model with $\mathrm{CuK}_{\alpha}$ tubes, in the range of $3-65^{\circ}(2 \theta)$ and 1 s at each step. 


\subsection{Microbial strains}

The bacteria used in the assays were obtained in the Laboratory of Microbiology and Molecular Biology - LMBM, of Regional University of Cariri - URCA. So, it was used Gram positive (Staphylococcus aureus ATCC 25923 and a multidrug resistant S. aureus 10) and Gram negative strains (Escherichia coli ATCC 25922, Pseudomonas aeruginosa ATCC 9027 and a multidrug resistant E. coli 06 and $P$. aeruginosa 15). The resistance profile was previously described by Lima et al [26].

\subsection{Antibacterial and antibiotic assays}

For this assay, it was performed the microdilution method using microtiter plates with 96 wells [27]. The assays of antibacterial and modulatory-antibiotic activity were performed as reported by Coutinho et al. [12]. All assays were performed in triplicate and using the follow compounds: OEHM, $\beta-\mathrm{CD}$ and the inclusion complex obtained by SC method with concentrations ranging between 1024 and $1 \mu \mathrm{g} / \mathrm{mL}$. The microtiter plates were incubated by $24 \mathrm{~h}$ at $37^{\circ} \mathrm{C}$. The Minimum Inhibitory Concentration (MIC) was determined using $20 \mu \mathrm{L}$ of resazurine $0.01 \%$ on each well and observing the change of colour. The MIC is defined as the lower concentration that inhibits the bacterial growth [28].

\subsection{Statistical analysis}

The bacterial results were analysed using the geometric means followed by ANOVA two-way with Bonferroni post hoc test $(P<0.05$ is considered significant $)$.

\section{Results and discussion}

\subsection{Complexation of EOHM in $\beta-C D$}

The DSC curve of EOHM showed an endothermic event at temperature range $28-140{ }^{\circ} \mathrm{C}$ corresponding to its volatilization (Fig 1). The $\beta$-CD curve showed three endothermic events followed by an exothermic and subsequent decomposition step. The endothermic events occurred in the range 32-121, 205-240 and $285-344^{\circ} \mathrm{C}$. The first endothermic event was related to water loss of $\beta-C D$ [29] and the second endothermic event was a physical process attributed to the change of crystalline phase [30]. Then there was observed melting followed by degradation of $\beta-C D$.

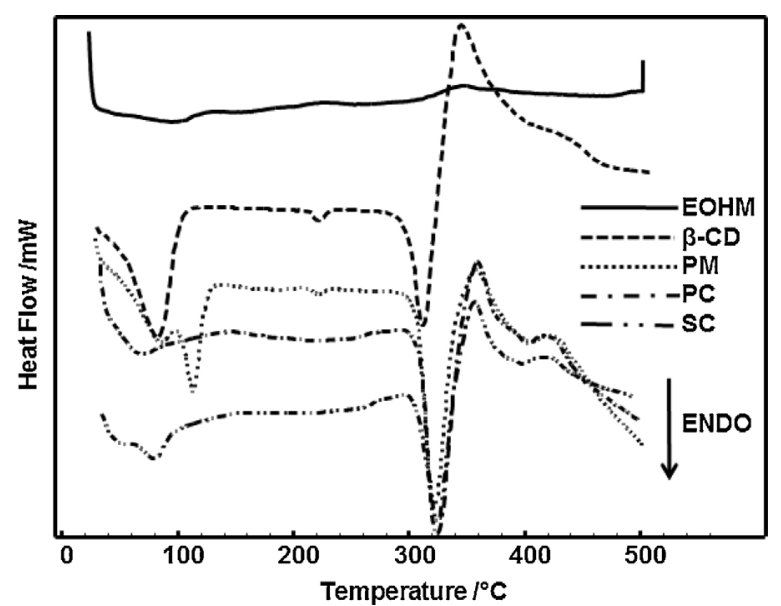

Fig. 1. DSC curves in dynamic $\mathrm{N}_{2}$ atmosphere of EOHM, $\beta-C D, P M$ and the complex EOHM: $\beta-C D$ obtained from PC and SC methods.
The DSC curve of PM presented four endothermic events followed by decomposition. The events occurred in the following temperature ranges: $67-97,99-132,212-234$ and $292-356^{\circ} \mathrm{C}$. The first two events represented a sum of EOHM and $\beta-C D$. The third peak corroborated crystalline phase transition of $\beta-C D$ and finally, the melting of $\beta-C D$ followed by decomposition.

DSC curves of PC and SC were different from PM and isolated raw materials and showed endothermic peaks followed by decomposition. In the PC events occurred in the following temperature range: $30-148$ and $295-358^{\circ} \mathrm{C}$. In the SC curve, the endothermic events occurred at $35-61,62-134$ and $297-356^{\circ} \mathrm{C}$. In curves of these last two methods were observed significant differences mainly related to the reduction of the intensity of the peak corresponding to loss of water and disappearance of the endothermic event related to crystalline phase transition of the pure $\beta-C D$.

The formation of inclusion complexes was also studied by TG/ DTG curves of EOHM, $\beta-C D, P M, P C$ and SC samples. Fig. 2 shows the TG/DTG curves of the samples and Table 1 lists mass losses calculated from specific intervals for each material studied in this paper and water percentages calculated by the Karl Fischer method.

The TG results showed that the EOHM volatilized up to $170^{\circ} \mathrm{C}$, with a weight loss of $100 \%$ as showed in the DSC technique. In the same temperature $\beta-\mathrm{CD}$ showed mass loss of $12.2 \%\left(\%_{\mathrm{H} 2 \mathrm{O}}=13.42\right)$ attributed to the molecule dehydration (Step 1). Furthermore, between 170 and $280^{\circ} \mathrm{C}$, there was no significant weight loss, characterizing the crystalline phase transition described in the corresponding DSC curve. Thermal decomposition occurred after $280^{\circ} \mathrm{C}$ and through the DTG curve, it was confirmed that the maximum decomposition temperature of $\beta-C D$ is $343^{\circ} \mathrm{C}$ [31]. In PC and SC curves, it was observed that in the range of $170-280^{\circ} \mathrm{C}$ (Table 1) the mass losses were 6.0 and $6.9 \%$, respectively. These weight loss percentages were attributed to release of complexed EOHM, since the free oil and $\beta-C D$ had no significant weight loss at this stage. In addition, the PM curve showed a low percentage of weight loss in the same step, suggesting that this preparation method is not effective in the complexation of EOHM in the $\beta-C D$ cavity. Furthermore, through the percentage of water values obtained by Karl Fischer titration, as shown in Table 1, it was observed a decrease in the percentage of water in the complex when compared with the $\beta-C D$. This decrease can be indicative of the formation of the inclusion complex, since the water molecules of $\beta-C D$ cavity were replaced by guest molecules [32].

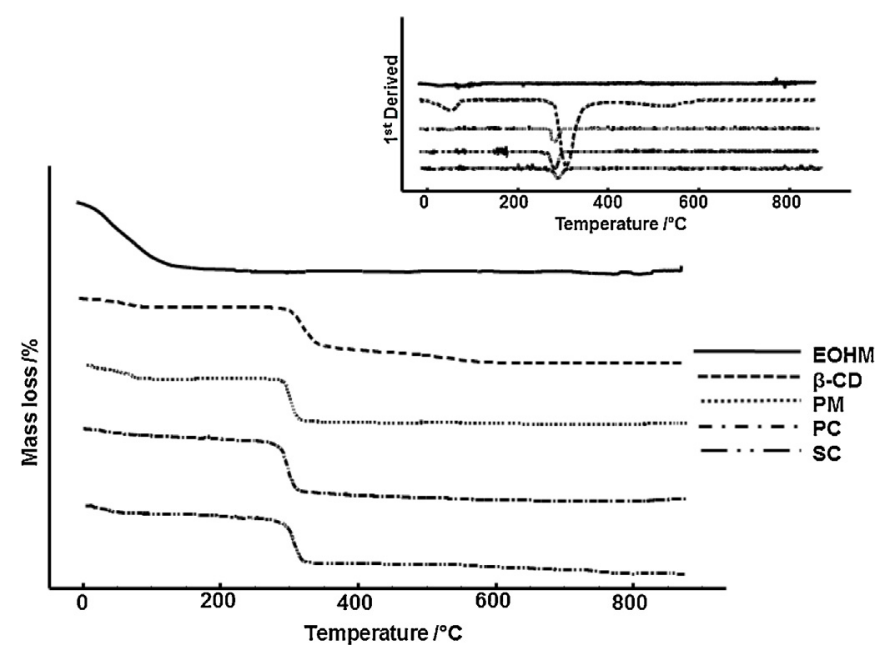

Fig. 2. TG/DTG curves in dynamic $N_{2}$ atmosphere of EOHM, $\beta-C D, P M$ and the complex EOHM: $\beta-C D$ obtained from PC and SC methods. 
Table 1

Mass loss percentage obtained by TG of EOHM, PM, PC and SC and Water percentages calculated by Karl Fischer titration.

\begin{tabular}{llllll}
\hline Sample & $\% \mathrm{H}_{2} \mathrm{O}(\mathrm{KF})$ & $\Delta m_{1}(\%)$ & $\Delta m_{2}(\%)$ & $\Delta m_{3}(\%)$ & $\Delta m_{4}(\%)$ \\
& & $30-170{ }^{\circ} \mathrm{C}$ & $170-280{ }^{\circ} \mathrm{C}$ & $280-400{ }^{\circ} \mathrm{C}$ & $400-900{ }^{\circ} \mathrm{C}$ \\
\hline EOHM & $0.52 \pm 0.03$ & 100.0 & - & - & - \\
$\beta-C D$ & $13.42 \pm 0.69$ & 12.2 & 0.3 & 65.1 & 22.4 \\
PM & $13.55 \pm 0.58$ & 18.4 & 0.5 & 69.1 & 12.0 \\
PC & $12.00 \pm 0.38$ & 13.1 & 6.0 & 84.2 & 6.7 \\
SC & $12.59 \pm 0.24$ & 10.2 & 6.9 & 70.1 & 12.8 \\
\hline
\end{tabular}

Fig. 3 shows the SEM images of $\beta-C D, P M, P C$ and SC, in different magnifications. The $\beta-C D$ showed different sizes crystals of rectangular shape with some particles adhered on its surface, as already described by other authors [33,34]. In referring to the PM micrograph, no difference was observed between the particles shape compared with the $\beta-C D$, suggesting the low complexing ability of this method as reported by the thermoanalytical techniques described above. As for the PC and SC samples, they exhibited different forms when compared to PM and $\beta-C D$. These preparations appeared in the form of pellets with a porous surface
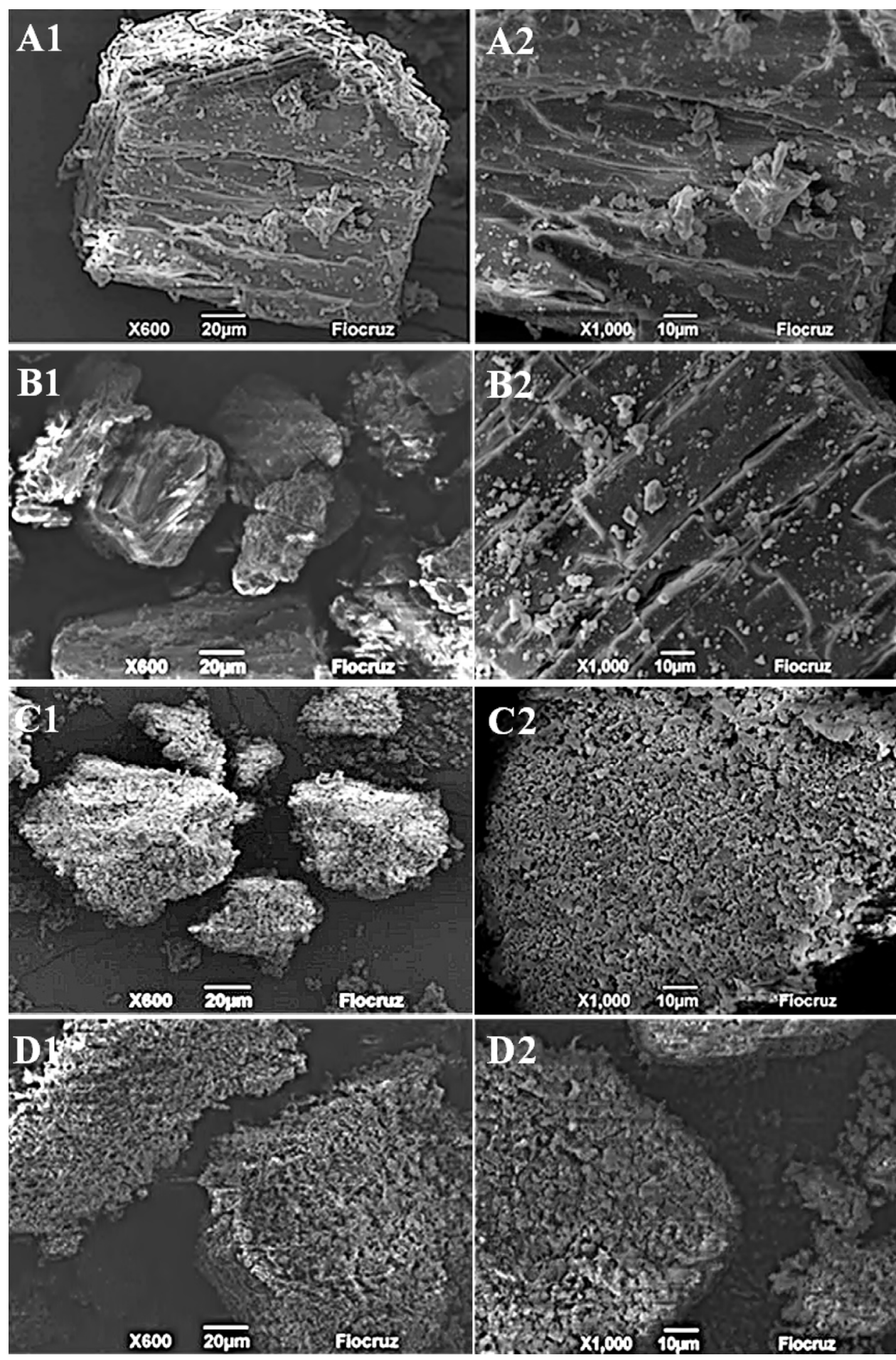

Fig. 3. Photomicrographs of cross-sections ( 20 and $10 \mu \mathrm{m}, 1$ and 2, respectively) of A: $\beta-C D, B: P M, C$ and D: EOHM: $\beta$-CD obtained by PC and SC methods, respectively. 


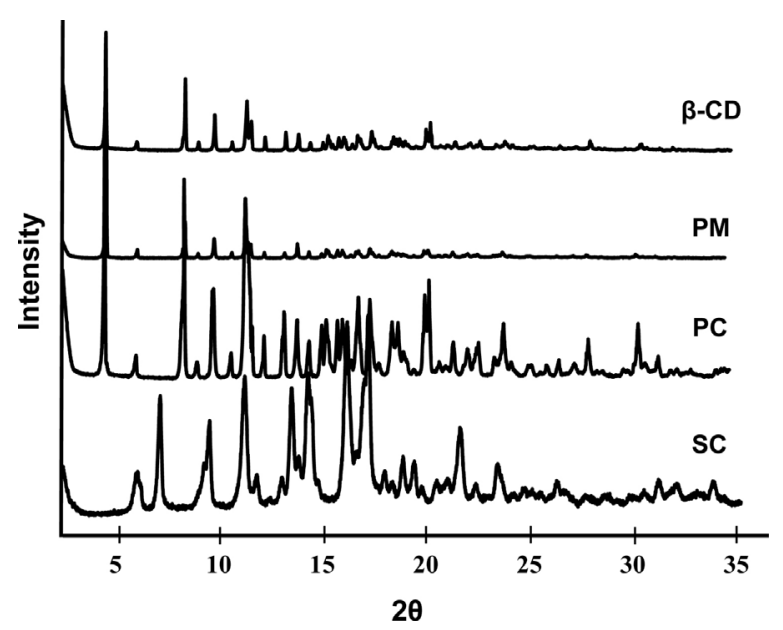

Fig. 4. X-ray diffractograms of $\beta-C D$, PM and the complex EOHM: $\beta-C D$ obtained from PC and SC methods.
Table 2

Minimum inhibitory concentration values $(\mu \mathrm{g} / \mathrm{ml})$.

\begin{tabular}{lllllll}
\hline Substances & \multicolumn{6}{l}{ Bacteria } \\
\cline { 2 - 7 } & S.A. & P.A. & E.C. & S.A. & P.A. & E.C. \\
& ATCC & ATCC & ATCC & 10 & 15 & 06 \\
& 25923 & 9027 & 25922 & & & \\
\hline$\beta-C D$ & $\geq 1024$ & $\geq 1024$ & $\geq 1024$ & $\geq 1024$ & $\geq 1024$ & $\geq 1024$ \\
EOHM & 32 & $\geq 1024$ & $\geq 1024$ & $\geq 1024$ & $\geq 1024$ & $\geq 1024$ \\
EOHM: $\beta-C D$ & $\geq 1024$ & $\geq 1024$ & $\geq 1024$ & $\geq 1024$ & $\geq 1024$ & $\geq 1024$ \\
\hline
\end{tabular}

S.A. - Staphylococcus aureus; P.A. - Pseudomonas aeruginosa; E.C. - Escherichia coli; $\beta-C D$ - $\beta$-cyclodextrin; EOHM - essential oil of Hyptis martiusii.

revealing an apparent interaction in the solid state between the EOHM and $\beta-C D$.

Additionally, X-ray diffraction analysis (Fig. 4) has observed the crystalline nature of the samples. Fig. 4 shows that the $\beta$-CD had many reflections, features of its crystalline structure. In the PM was observed some $\beta-C D$ characteristics with substantial reductions in the intensity, suggesting amorphization process. PC and SC were seen some $\beta-C D$ reflections and the appearance of new peaks,

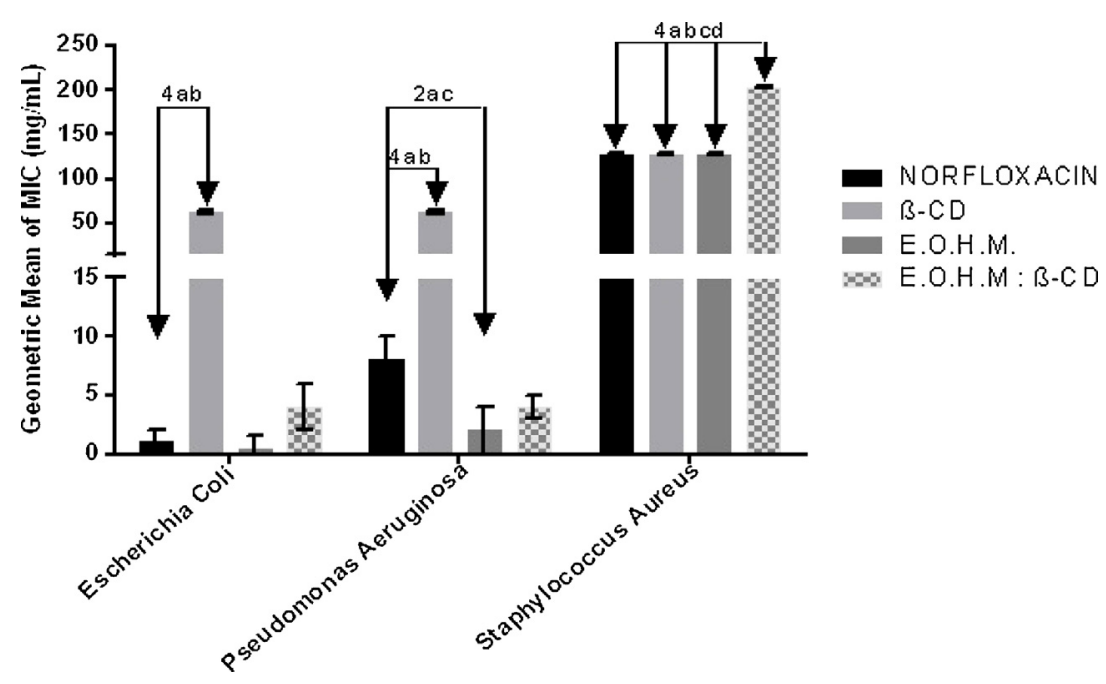

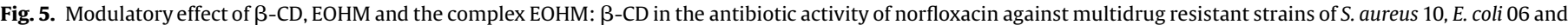

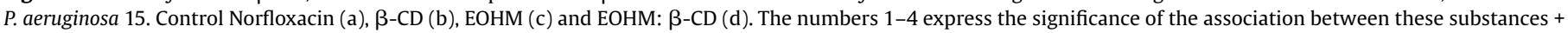
norfloxacin. The number 4 means $P<0.0001$ when compared with the control.

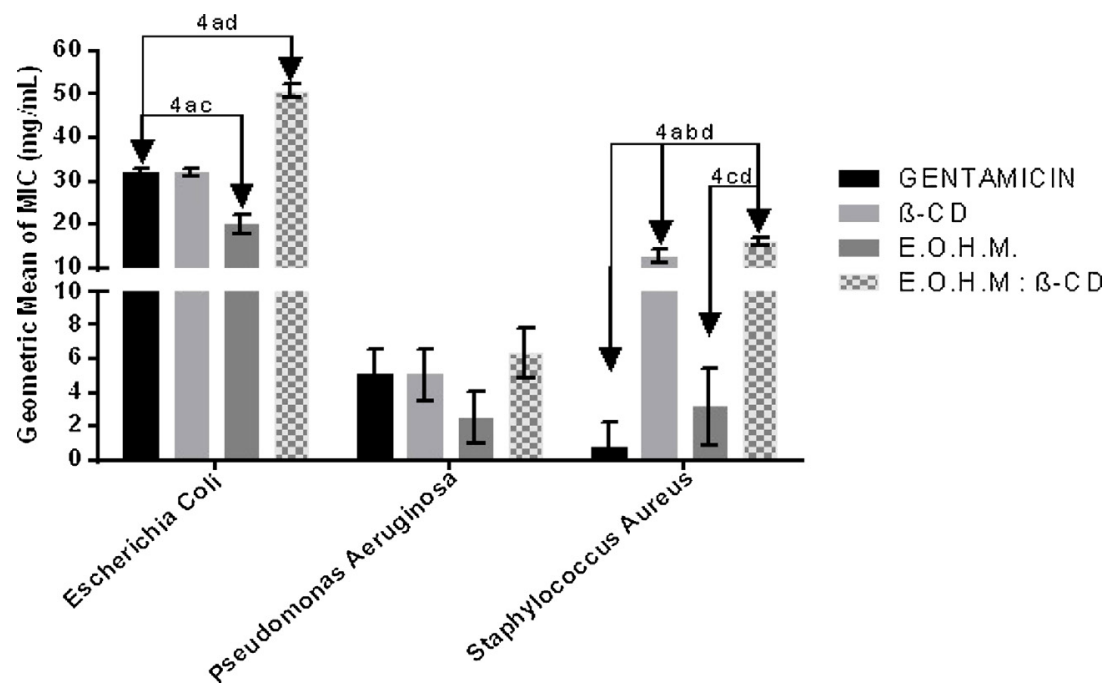

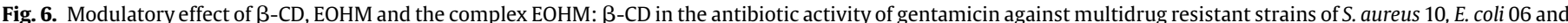

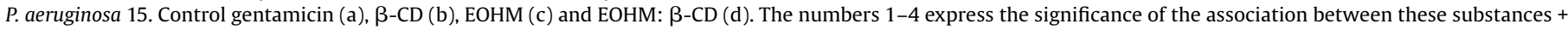
gentamicin. The number 4 means $P<0.0001$ when compared with the control. 
which indicated the formation of a new solid phase, thus indicating the formation of the inclusion complex EOHM/ $\beta-C D$. Similar results were obtained by Toropainen [35].

\subsection{Antibacterial activity}

The antimicrobial activity was evaluated by Minimum Inhibitory Concentration - MIC (Table 2). The MICs for all compounds were $\geq 1024 \mu \mathrm{g} / \mathrm{mL}$, except when the essential oil of Hyptis Martiusii was used against Staphylococcus aureus ATCC 25923 (MIC $=32 \mu \mathrm{g} / \mathrm{mL}$ ), according with previous work by Coutinho et al. [12].

The essential oils of several plants from the genus Hyptis demonstrated the best result against Gram-positive bacteria. This fact can be explained due the external membrane present on Gram-negative bacteria, with suppress the association of the lipophilic compounds of the essential oil with the cell membrane [36,37].

Besides all effects reported as solubility enhancement, better adherence to the bacterial cell wall and higher bioavailability of the drug [38], the $\beta-C D$ alone or associated with the EOHM demonstrated a MIC $\geq 1024 \mu \mathrm{g} / \mathrm{mL}$. Assays using gama-CD revealed none effect against none strains of $S$. aureus, E. coli and $P$. aeruginosa [39] demonstrating that $C D$ has not an increased antibiotic activity.

\subsection{Antibiotic modulatory effect}

The EOHM demonstrated a synergism when in association with norfloxacin against $P$. aeruginosa 15 , with a MIC reduction of 8 for $2 \mu \mathrm{g} / \mathrm{mL}$ (Fig. 5). This effect can be explained by the high amount of terpenes in the EOHM that enhances the influx of antibiotics by alterations in the cell membrane permeability [40].

$\beta-C D$ demonstrated different antagonistic effect when associated with the antibiotics and against all bacteria assayed. This antagonism effect from the chelating effect of the $\beta-C D$ with the antibiotics $[41,42]$.

The complex EOHM: $\beta-\mathrm{CD}$ demonstrated higher MICs when compared with the EOHM alone, demonstrating that interaction with the $\beta-C D$ affected the modulatory effect of the EOHM. Thus, the inclusion complexes demonstrated different physicochemical properties in comparison with the pure compounds, indicating the existence of new manner or molecular organization and chemical interaction with cell systems [43].

Associated with the gentamicin, the EOHM demonstrated synergism against $E$. coli 06 , reducing the MIC of $32-20.15 \mu \mathrm{g} / \mathrm{mL}$ (Fig. 6). Similar results were observed in the essential oil of Cymbopogon citratus, a natural complex rich in compounds as terpenes that reduced the MIC of E. coli of $156.25-39.06 \mu \mathrm{g} / \mathrm{mL}$ [44].

Other works using natural products from Hyptis Martiusii as the ethanol extract demonstrated a synergism against the strain $E$. coli 27. This fact was associated with the inhibition of efflux systems identified in this bacterium by the use of chlorpromazine (CPZ), causing the same synergistic effect [45] and revealing the possible mechanism of antibiotic activity enhancement.

The $\beta-C D$ did not demonstrate any modulatory effect against the assayed Gram negative bacteria using gentamicin, however, against the Gram positive one, the effect was an antagonism. When associated with the gentamicin, the complex EOHM: $\beta-C D$ demonstrated antagonism against the Gram negative and Gram positive bacteria assayed. When compared with the essential oil alone, we can observe that the complexation with $\beta-C D$ affect directly the modulatory activity of the EOHM [46,47].

\section{Conclusions}

Based on these results, it was possible to observe that the complexation of EOHM in $\beta$-CD cavity occurred in the preparations of PC and SC. Additionally, the second stage of TG $\left(170-280^{\circ} \mathrm{C}\right)$ showed that the SC was the best method since the inclusion showed a weight loss of $6.9 \%$, suggesting that the complexed oil required a higher temperature to decompose compared to free EOHM, that lost $100 \%$ of its mass up to $170^{\circ} \mathrm{C}$.

The results obtained demonstrated the anti-staphylococcal activity of EOHM and a synergistic effect when associated with the gentamicin against the Gram negative bacteria. Indeed, this essential oil is a potential source of compounds to be used in the treatment of bacterial infections. However, the complex EOHM: $\beta-C D$ and $\beta-C D$ alone have not antibacterial neither modulatory antibiotic activity. This result is related with the $\beta-C D$ do not interect directly with the lipid bilayer as occur with the EOHM alone. Due this fact, the $\beta-C D$ do not disrupt neither affect the cell membrane.

\section{Acknowledgements}

We would like to thank the Conselho Nacional de Desenvolvimento Científico e Tecnológico/CNPq/Brazil and Fundação de Amparo à Pesquisa do Estado de Sergipe/FAPITEC-SE for the financial support.

\section{References}

[1] L.K. Souza, C. Oliveira, P.H. Ferri, J.G.D. Oliveira Júnior, A.H.D. Souza Júnior, O.D. F.L. Fernandes, M.D.R.R. Silva, Antimicrobial activity of Hyptis ovalifolia towards dermatophytes, Memórias do Instituto Oswaldo Cruz. 98 (2003) 963-965.

[2] R. Pereda-Miranda, L. Hernández, M.J. Villavicencio, M. Novelo, P. Ibarra, H. Chai, J.M. Pezzuto, Structure and stereochemistry of pectinolides AC, novel antimicrobial and cytotoxic 5, 6-dihydro- $\alpha$-pyrones from Hyptis pectinata, J. Nat. Prod. 56 (1993) 583-593.

[3] C. Takayama, F.M. de-Faria, A.C.A. de Almeida, C.S. Rehen, R.J. Dunder, E.A.R Socca, C.A. Hiruma-Lima, Gastroprotective and ulcer healing effects of essential oil from Hyptis spicigera Lam. (Lamiaceae), J. Ethnopharmacol. 135 (2011) 147-155.

[4] I.A. Menezes, M.S. Marques, T.C. Santos, K.S. Dias, A.B. Silva, I.C. Mello, A.R. Antoniolli, Antinociceptive effect and acute toxicity of the essential oil of Hyptis fruticosa in mice, Fitoterapia 78 (2007) 192-195.

[5] M.D. Bispo, R.H.V. Mourão, E.M. Franzotti, K.B.R. Bomfim, M.D.F. ArrigoniBlank, M.P.N. Moreno, A.R. Antoniolli, Antinociceptive and antiedematogenic effects of the aqueous extract of Hyptis pectinate leaves in experimental animals, J. Ethnopharmacol. 76 (2001) 81-86.

[6] P. Dos, P. Menezes, A.A.S. Araujo, A.A. Doria, L.J. Quintans-Junior, M.G.B. Oliveira, M.R.V. dos Santos, I.L. Matos, Physicochemical characterization and analgesic effect of inclusion complexes of essential oil from Hyptis pectinata L. Poit leaves with $\beta$-cyclodextrin, Curr. Pharm. Biotechnol. 16 (2015) 440-450.

[7] C.D.F.C. Almeida, U.P. Albuquerque, Check-list of the family Lamiaceae in Pernambuco, Brazil, Braz. Arch. Biol. Techn. 45 (2002) 343-353.

[8] M.D.F. Agra, K.N. Silva, I.J.L.D. Basílio, P.F.D. Freitas, J.M. Barbosa-Filho, Survey of medicinal plants used in the region Northeast of Brazil, Rev. Bras. Farmacogn. 18 (2008) 472-508.

[9] L.V. Costa-Lotufo, E.C.C. Araujo, M.A.S. Lima, M.E.A. Moraes, C. Pessoa, E.R Silviera, M.O. Moraes, Antiproliferative effects of abietane diterpenoids isolated from Hyptis martiusii Benth (Labiatae), Pharmazie 59 (2004) 78-79.

[10] E.C.D.C. Araújo, M.A.S. Lima, R.C. Montenegro, M. Nogueira, L.V. Costa-Lotufo, C. Pessoa, E.R. Silveira, Cytotoxic abietane diterpenes from Hyptis martiusii Benth, Z. Naturforsch C. 61 (2006) 177-183.

[11] J.G.M. Costa, F.F.G. Rodrigues, E.C. Angélico, M.R. Silva, M.L. Mota, N.K.A. Santos, T.L.G. Lemos, Chemical-biological study of the essential oils of Hyptis martiusii, Lippia sidoides and Syzigium aromaticum against larvae of Aedes aegypti and Culex quinquefasciatus, Rev. Bras. Farmacogn. 15 (2005) 304-309.

[12] H.D.M. Coutinho, J.G.M. Costa, J.P. Siqueira-Júnior, E.O. Lima, In vitro antistaphylococcal activity of Hyptis martiusii Benth against methicillin-resistant Staphylococcus aureus: MRSA strains, Rev. Bras. Farmacogn. 18 (2008) 670-675.

[13] G.F.R. Caldas, I.M. Amaral Costa, J.B.R. Silva, R.F. Nóbrega, F.F.G. Rodrigues, J.G. M. Costa, A.G. Wanderley, Antiulcerogenic activity of the essential oil of Hyptis martiusii Benth. (Lamiaceae), J. Ethnopharmacol. 137 (2011) 886-892.

[14] D.J. Daferera, B.N. Ziogas, M.G. Polissiou, The effectiveness of plant essential oils on the growth of Botrytis cinerea, Fusarium sp. and Clavibacter michiganensis subsp. michiganensis, Crop Protect. 22 (2003) 39-44. 
[15] R.J. Pereira, M.G. Cardoso, Vegetable secondary metabolites and antioxidants benefits, J. Biotechnol. Biodivers. 3 (2012) 146-152.

[16] L.S. Nerio, J. Olivero-Verbel, E. Stashenko, Repellent activity of essential oils: a review, Bioresource Technol. 101 (2010) 372-378.

[17] E.C. Araújo, E.R. Silveira, M.A.S. Lima, M.A. Neto, I.L. Andrade, M.A.A. Lima, A.L. M. Mesquita, Insecticidal activity and chemical composition of volatile oils from Hyptis martiusii Benth, J. Agr. Food Chem. 51 (2003) 3760-3762.

[18] R.N. Marreto, E.E. Almeida, P.B. Alves, E.S. Niculau, R.S. Nunes, C.R. Matos, A.A. Araújo, Thermal analysis and gas chromatography coupled mass spectrometry analyses of hydroxypropyl- $\beta$-cyclodextrin inclusion complex containing Lippia gracilis essential oil, Thermochim. Acta 475 (2008) 53-58.

[19] R.A. Rajewski, V.J. Stella, Pharmaceutical application of cyclodextrins. In vivo drug delivery, J. Pharm. Sci. 85 (1996) 1142-1169.

[20] L. Zhang, D. Pornpattananangkul, C.M. Huang, C.M. Hu, Development of nanoparticles for antimicrobial drug delivery, Curr. Med. Chem. 17 (2010) 585594.

[21] J. Li, X.J. Loh, Cyclodextrin-based supramolecular architectures: syntheses, structures, and applications for drug and gene delivery, Adv. Drug. Deliver. Ver 60 (2008) 1000-1017.

[22] Y.Y. Hwang, D.C. Shin, Y.S. Nam, B.K. Cho, Characterization, stability, and pharmacokinetics of sibutramine/ $\beta$-cyclodextrin inclusion complex, J. Ind. Eng. Chem. 18 (2012) 1412-1417.

[23] J. Liu, L. Qiu, J. Gao, Y. Jin, Preparation, characterization and in vivo evaluation of formulation of baicalein with hydroxypropyl- $\beta$-cyclodextrin, Int. J. Pharm. 312 (2006) 137-143.

[24] M.F. Wempe, V.J. Wacher, K.M. Ruble, M.G. Ramsey, K.J. Edgar, N.L. Buchanan, C. M. Buchanan, Pharmacokinetics of raloxifene in male Wistar-Hannover rats: influence of complexation with hydroxybutenyl-beta-cyclodextrin, Int. J. Pharm. 346 (2008) 25-37.

[25] K. Uekama, M. Otagiri, Cyclodextrins in drug carrier systems, Crit. Rev. Ther. Drug 3 (1986) 1-40.

[26] V.N. Lima, C.D.M. Oliveira-Tintino, E.S. Santos, L.P. Morais, S.R. Tintino, T.S Freitas, Y.S. Geraldo, R.L.S. Pereira, R.P. Cruz, I.R.A. Menezes, H.D.M. Coutinho, Antimicrobial and enhancement of the antibiotic activity by phenolic compounds: gallic acid, caffeic acid and pyrogallol, Microb. Pathogen. 99 (2016) 56-61.

[27] Clinical and Laboratory Standards Institute, Methods for Dilution Antimicrobial Susceptibility Tests for Bacteria That Grow Aerobically, 8th ed., CLSI, 2008.

[28] G.W.P. Sales, A.H.M. Batista, L.Q. Rocha, N.A.P. Nogueira, Efeito antimicrobiano e modulador do óleo essencial extraído da casca de frutos da Hymenaea courbaril, L. Rev. Ciênc. Farm. Básica Apl. 35 (2014) 709-715.

[29] S. Scirè, S. Giuffrida, C. Crisafulli, P.M. Riccobene, A. Pistone, Liquid phase photo-deposition in the presence of unmodified $\beta$-cyclodextrin: a new approach for the preparation of supported Pd catalysts, J. Mol Catal. A-Chem. 353 (2012) 87-94.

[30] P. Guo, Y. Su, Q. Cheng, Q. Pan, H. Li, Crystal structure determination of the $\beta$-cyclodextrin-p-aminobenzoic acid inclusion complex from powder X-ray diffraction data, Carbohydr. Res. 346 (2011) 986-990.

[31] G. Astray, C. Gonzalez-Barreiro, J.C. Mejuto, R. Rial-Otero, J. Simal-Gándara, A review on the use of cyclodextrins in foods, Food Hydrocolloid. 23 (2009) 1631-1640.

[32] M.R. Serafini, P.P. Menezes, L.P. Costa, C.M. Lima, L.J. Quintans Jr., J.C. Cardoso, J. R. Matos, J.L. Soares-Sobrinho, S. Grangeiro Jr., P.S. Nunes, L.R. Bonjadim, A.A.S.
Araújo, Interaction of p-cymene with $\beta$-cyclodextrin, J. Therm. Anal. Calorim. 109 (2012) 951-955.

[33] N.G. Hădărugă, Ficaria verna Huds. extracts and their b-cyclodextrin supramolecular systems, Chem. Cent. J. 6 (2012) 16.

[34] S. Songkro, N. Hayook, J. Jaisawang, D. Maneenuan, T. Chuchome, N. Kaewnopparat, Investigation of inclusion complexes of citronella oil, citronellal and citronellol with $\beta$-cyclodextrin for mosquito repellent, J. Incl. Phenom. Macrocycl. Chem. 72 (2012) 339-355.

[35] T. Toropainen, S. Velaga, T. Heikkilä, L. Matilainen, P. Jarho, J. Carlfors, K. Järvinen, Preparation of budesonide $/ \gamma$-cyclodextrin complexes in supercritical fluids with a novel SEDS method, J. Pharm. Sci. 95 (2006) 2235-2245.

[36] W. Nantitanon, S. Chowwanapoonpohn, S. Okonogi, Antioxidant and antimicrobial activities of Hyptis suaveolens essential oil, Sci. Pharm. 75 (2007) 35.

[37] P.O. Santos, M.D.J.C. Costa, J.A.B. Alves, P.F.C. Nascimento, D.L.F.M. Melo, A.M. Barbosa Jr., R.C. Trindade, A.F. Blank, M.F. Arrigoni-Blank, P.B. Alves, M.P.F. Nascimento, Chemical composition and antimicrobial activity of the essential oil of Hyptis pectinata, Poit. Quim Nova 31 (2008) 1648-1652.

[38] K.I.R. Teixeira, Estudo das alterações da membrana celular de Microorganismos por compostos de inclusão de clorexidrina:Betaciclodextrina em diferentes proporções molares usando microscopia de força atômica e microscopia eletrônica de varredura, Dissertação de Mestrado, Faculdade de Odontologia, Universidade Federal de Minas Gerais, 2008.

[39] V. Hanci, A. Vural, S.Y. Hanci, H.A. Kiraz, D. Ömür, A. Ünver, Avalição in vitro das características antimicrobianas de sugamadex, Rev. Bras. Anestesiol. 64 (2014) $105-108$

[40] D.S. Ribeiro, D.B. Melo, A.G. Guimarães, E.S. Velozo, Avaliação do óleo essencial de alecrim (Rosmarinus officinalis L.) como modulador da resistência bacteriana, Semina: Ciências Agrárias 33 (2012) 687-696.

[41] E.V. Granowitz, R.B. Brown, Antibiotic adverse reactions and drug interactions, Crit Care Clin. 24 (2008) 421-442.

[42] N.L.F. Pereira, P.E.A. Aquino, E.M. Nascimento, C.D.M. Oliveira, S.R. Tintino, F.G. Figueredo, M.R. Silva, H.N.H. Veras, A.R.S. Grangeiro, I.R.A. Menezes, Efeito antibacteriano e anti-inflamatório tópico de Chenopodium ambrosioides L, Rev. Fitos. 9 (2015) 73-159.

[43] Nanoagregados baseados em ciclodextrinas em associação com a tetraciclina: caracterização físico-química e avaliação antimicrobiana, Tese de Mestrado, Faculdade de Odontologia, Universidade Federal de Minas Gerais, 2007.

[44] F.B. Lucena, S.R. Tintino, F.G. Figueredo, C.D.M. Oliveira, J.J.S. Aguiar, E.A.N. Cardoso, P.E. Aquino, J.C. Andrade, H.D.M. Coutinho, E.F.M. Matias, Avaliação da Atividade Antibacteriana e Moduladora de Aminoglicosídeos do Óleo Essencial de Cymbopogon citratus (DC.) Stapf, Acta Biol. Colomb. 20 (2015) 39-45.

[45] H.D.M. Coutinho, J.G. Costa, E.O. Lima, V.S. Falcão-Silva, J.P. Siqueira-Júnior, In vitro interference of Hyptis martiusii Benth \& chlorpromazine against an aminoglycoside-resistant Escherichia coli, Indian J. Med. Res. 129 (2009) 566568.

[46] G.F.R. Caldas, A.V. Araújo, G.S. Albuquerque, J.C. Silva-Neto, J.H. Costa-Silva, I.R. A. Menezes, A.C.L. Leite, J.G.M. Costa, A.G. Wanderley, Repeated-doses toxicity study of the essential oil of Hyptis martiusii Benth (Lamiaceae) in Swiss Mice, J. Evid. Based Complement. Altern. Med. 2013 (2013) 1-11.

[47] D.P. Rocha, G.F. Pinto, R. Ruggiero, C.A. Oliveira, W. Guerra, A.P.S. Fontes, T.T. Tavares, I.M. Marzano, E.C. Pereira-Maia, Coordenação de metais a antibióticos como uma estratégia de combate à resistência bacteriana, Quím. Nova 34 (2011) 111-118. 